\title{
Cdc23/Mcm10 Primase Generates the Lagging Strand-Specific Ribonucleotide Imprint in Fission Yeast
}

\author{
Balveer Singh $^{2}$, Kamlesh K, Bisht ${ }^{3}$, Udita Upadhyay ${ }^{4}$, Avinash Chandra Kushwaha ${ }^{5}$, \\ Jagpreet Singh Nanda ${ }^{6}$, Suchita Srivastava ${ }^{1}$, Amar J.S. Klar and Jagmohan Singh ${ }^{1 *}$ \\ ${ }^{1}$ Institute of Microbial Technology, Sector 39A, Chandigarh-160036. India \\ ${ }^{2}$ Institute of Genetics and Development of Rennes Faculte de Medecine Campus santé de Villejean 2 \\ avenue du Professor Leon Bernard CS 3431735043 Rennes Cedex France \\ ${ }^{3}$ Translational Discovery Biology, (Immuno-Oncology), Bristol-Myers Squibb Route 206 \& Province Line \\ Road, Princeton, NJ 08543, USA \\ ${ }^{5}$ Institute of Nano Science and Technology, Phase 10, Mohali - 160062 \\ ${ }^{4}$ Department of Anesthesiology, RMSB 8022, 1600 NW, 10th Ave, Miami, FL 33136, USA \\ ${ }^{6}$ Department of Pharmacology, Case Western Reserve University, 10900 Euclid Ave, Cleveland, OH \\ 44106, USA \\ ${ }^{2,3}$ Equal contribution \\ *Corresponding Author
}

Running Title: Mcm10 installs ribonucleotide imprint

Key words: Imprinting, fission yeast, mat1, Cdc23/Mcm10 


\begin{abstract}
:
The developmental asymmetry of fission yeast daughter cells derives from inheriting "older Watson" versus "older Crick" DNA strand from the parental cell, strands that are complementary but not identical with each other. A novel DNA strand-specific "imprint", installed during DNA replication at the mating-type locus (mat1), imparts competence for cell type inter-conversion to one of the two chromosome replicas. The biochemical nature of the imprint and the mechanism of its installation are still not understood. The catalytic subunit of DNA Polymerase $\alpha$ (Pol $\alpha$ ) has been implicated in the imprinting process. Based on its known biochemical function, Pol $\alpha$ might install the matl imprint during lagging strand synthesis. The nature of the imprint is not clear: it is either a nick or a ribonucleotide insertion. Our investigations do not support a role of Pol $\alpha$ in nicking through putative endonuclease domains but confirm its role in installing an alkali-labile moiety as the imprint. A detailed genetic and molecular analysis reveals a direct role of the $\mathrm{Cdc} 23 / \mathrm{Mcm} 10$ primase activity in installing the imprint in cooperation with Pol $\alpha$ and Swil.
\end{abstract}




\section{INTRODUCTION}

In Schizosaccharomyces pombe, the mating-type region comprises three loci located on chromosome II: mat $1 M$ or $P$, mat $2 P$ and mat3M (Fig. 1A). The mat1 cassette is expressed and it dictates the Plus or Minus sex/cell type to the cell. The mat $2 P$ and $m a t 3 M$ cassettes, which are transcriptionally silenced by an epigenetic mechanism, function as master copies for switching mat1. Switching occurs by highly regulated recombination through transposition/substitution of the mat1 allele with the opposite mating-type information, copied from either mat $2 P$ or mat $3 M$ cassettes [1-4]. The mating-type switching process is exquisitely regulated in very interesting ways. First, of the four "granddaughter" cells derived from a single cell, only one cell switches in nearly $90 \%$ of pedigrees $[2,5,6]$. This pattern results from asymmetric cell division occurring in each of the two consecutive generations in the progeny of a single cell. The switching program is initiated by a novel "imprint," that is installed in specific DNA strand during replication of the mat 1 locus on chromosome II [1,2]. In the following cell division, the imprint consummates into a switch but only in one of the sister chromatids during mat1 replication. The mat1-switching event removes the imprint. The mat1 locus in the chromosome is replicated only in one direction. Chromosomal inversion of the matl "cassette" abolishes imprinting, which is partially restored by genetic manipulations promoting mat1 replication in the opposite direction [7]. Thus, replication of a specific matl strand specifically by the lagging-strand replication complex is critical for generating the imprint. The imprinting process requires three genes [8]: swil [9], swi3 [10] and swi7/pola [11]. Mechanistically, Swi1 and Swi3 create a replication pause at the imprint site. They also block replication forks originating from the centromeric side of mat1 [9]. The single swi71/pol $\alpha$ imprinting-deficient mutant, however, shows a normal pause and normal replication fork block, and is, therefore, defective at some other undefined step in 
imprinting pathway [9].

However, the nature of the imprint remains unresolved; it is thought to be either a site- and strand-specific nick [12] or an alkali-labile, RNase-sensitive modification, consisting of one or two ribonucleotides incorporated in matl DNA $[7,13,14]$. The imprint creates a DNA fragile site, which is artifactually converted into double-strand break (DSB) due to hydrodynamic shear when extracting DNA from cells $[7,12]$. Therefore, the imprint level is usually determined by quantifying the DSB at matl through Southern blot analysis.

The swi7 gene, encoding the catalytic subunit of Pol $\alpha$, is inherently required much more often in the lagging- than the leading-strand DNA synthesis during chromosome replication [11]. The biochemical role of Pol $\alpha / \mathrm{Swi}$ in generating the imprint has remained elusive. This is because it encodes a gene which is essential for viability, thus limiting its analysis; only one allele, swi7-1/pol $\alpha$, mapping to the carboxy-terminal region (G1116E) of the catalytic subunit of Pol $\alpha$, is known to affect imprinting [11]. Notably, the imprinting event occurs only on the newly synthesized lagging strand during S phase [15]. Since the Pol $\alpha /$ Primase complex can synthesize and extend an RNA moiety on DNA template, Pol $\alpha / \mathrm{Swi} 7$ is a plausible candidate for installing the imprint in the form of ribonucleotide(s) insertion at mat1, through the primase subunit. Alternatively, Pol $\alpha$-catalyzed DNA nicking may constitute the imprint [12]. 


\section{RESULTS AND DISCUSSION}

\section{Pol $\alpha$ catalytic subunit does not play a direct role in Imprinting}

This work was initiated to determine whether the catalytic subunit of Pol $\alpha$ may be directly involved in generating the imprint in the form of a nick at the matl locus. It was shown earlier that the DNA prepared by the normal method causes hydrodynamic shearing resulting in conversion of a nick into double strand break at the imprint site [12]. As a result the matl HindIII fragment of $10.6 \mathrm{~kb}$ is split into two bands of 5.6 and 5.0kb (Fig. 1B, 1C). According to this study, preparation of the DNA in agarose plugs avoids the hydrodynamic shear and mat1 DNA shows a nick in the top DNA strand as the putative imprint [12]. Assuming that Pol $\alpha$ may act as an endonuclease, we analyzed the sequence of Pol $\alpha$ for the presence of endonuclease motifs and found motifs similar to the putative intein endonuclease [16-18] and restriction endonucleases [19] (Expanded View, Fig. EV1A-D). We investigated whether these motifs play a role in imprinting. However, we found that the plasmids containing the mutated pol $\alpha$ gene complemented the swi7-1 mutation, ruling out a role of Pola as an endonuclease (Expanded View, Fig. EV1A-D). Surprisingly, we found that a catalytically dead version of Pol $\alpha$ (D984N mutant), which is unable to extend the RNA primers synthesized by the Pol $\alpha$-primase subunit [20], was actually proficient in restoring the imprint (detected as DSB using DNA prepared by the normal method) when transformed into swi7-1 mutant. The mutant plasmid did not complement the imprinting defect in the swil and swi3 mutants [Expanded View; Fig. EV2A].

As we were unable to identify any endonuclease function of Pol $\alpha$ in explaining the DNA nick, we considered the alternative possibility that the imprint may be due to the presence of ribonucleotide/s in the DNA chain, which is detectable as an alkalilabile bond [7]. Indeed, a break was indicated by a broad band at the putative imprint 
site, at 5.0-5.6kb region, in Southern blots of alkali-treated plugs of DNA digested with HindIII [Expanded View; Fig. EV2B, right panel]. Thus, the imprinting step does involve a ribonucleotide insertion as a step distinct from the replication function of Pola.

These results created a conundrum for us: how might the catalytically dead Pol $\alpha$ complement the imprinting defect of swi7-1 mutant? The pold ${ }^{D 984 N}$ mutation in the evolutionarily conserved Asp residue does not alter either the stability or assembly of the mutant Pol $\alpha$-primase complex [20-21]. Notably, the catalytic subunit mutant protein is unable to further extend RNA primers synthesized by the primase subunit [20-21]. We envisaged two possibilities: either the Pol $\alpha^{\text {Swi7-1 }}$ mutant protein complex is defective in the primase activity or in utilizing the RNA primer synthesized by the RNA primase subunit for DNA synthesis. To distinguish between these possibilities, we tested the imprinting and switching efficiency of temperature sensitive mutants in primase subunits of Pola: those of spp1-4, spp1-14 alleles of spp1 and spp2-8 allele of spp2 genes (Fig. EV3A) [22-24]. Although, somewhat reduced efficiency of switching was observed, especially in spp1-4 mutant (Fig. EV3B), the level of imprint/DSB was affected in these mutants to an extent similar to the wt strain when cultured at semi-permissive growth temperature of $34^{\circ} \mathrm{C}$ (Fig. EV3C). Thus, these data do not support a role of the Pol $\alpha$ primase subunit in matl imprinting. However, the extremely low rate of switching in the sppl-4 mutant at $34^{\circ} \mathrm{C}$ may be due to lower efficiency of utilization of the imprint for switching, as observed earlier in case of swi2, swi5 and swi6 mutants [8].

\section{Other Mcm components do not play role in imprinting}

Our findings indicated a role of DNA replication initiation in imprinting. Next, we queried whether the components of MCM-helicase complex, essential for DNA replication initiation, are required for imprinting (Fig. EV4A. We observed normal 
iodine staining of colonies of mutants in mcm2 (cdc19-p1) [25], mcm4 (cdc21-M68)

[26], mcm5 (nda4-108) [27] and mcm6 (mis5-268) [28], in homothallic $\left(h^{90}\right)$ background indicative of normal switching at permissive temperature $\left(25^{\circ} \mathrm{C}\right)$ and semi-permissive temperature $\left(30^{\circ} \mathrm{C}\right)$ (Expanded View; Fig. EV4B). This result argues against the role of earlier steps of replication initiation in imprinting.

\section{The Cdc23/SpMcm10 primase performs previously unknown imprinting function at mat1}

Because of a reported primase-like function of Cdc23/SpMcm10, we next investigated the efficiency of switching and mat1 imprinting of $c d c 23$ mutants (Fig. 2A). Notably, the $c d c 23-M 30$ and $c d c 23-M 36$ mutations are located in its Mcm/Pol $\alpha-$ interacting domain [29,30]. Both $c d c 23-M 30$ and $c d c 23-M 36$ mutants showed normal switching (Fig. 2B, top panel) and DSB/imprint (Fig. 2D, left panel) in cells grown at permissive temperature $\left(25^{\circ} \mathrm{C}\right)$ but showed reduced switching and DSB at $30^{\circ} \mathrm{C}$ semipermissive growth temperature (Fig. 2B, lower panel; Fig 2D, right panel, 2E). In contrast, the $c d c 23-1 E 2$ mutant, its mutation also mapping to the Mcm- and Pol $\alpha$ interacting domain (Fig. 2A), showed low switching efficiency (Fig. 2B. lower panel) and much reduced DSB/imprint at both growth temperatures (Fig. 2D, 2E). Importantly, $c d c 23-M 36$ mutant showed an alkali-labile bond at mat 1 at growth temperature of $25^{\circ} \mathrm{C}$ but not at $30^{\circ} \mathrm{C}$ semi-permissive temperature (Fig. 2C, 2F, right panel; compare lanes 6 and 8; 2G). Thus, Mcm- and Pol $\alpha$-interacting domain of $\mathrm{Cdc} 23$ plays a role in installing the alkali-labile imprint.

Previous structure-function analysis of $\mathrm{Cdc} 23$ has revealed three functional domains: Pol $\alpha$ - interaction domain, zinc domain and putative primase domain, having similarity to the bacteriophage $\mathrm{T} 7$ gene 4 primase (Fig. 2A) [29]. Because the primase mutants are inviable [29], we explored the role of Cdc23 domains in imprinting by 
genetic complementation experiments. We tested the ability of the high copy number plasmids bearing different $c d c 23$ mutant alleles to suppress the imprinting defect of the $c d c 23-M 36$ allele. While plasmids bearing wild-type $c d c 23^{+}, c d c 23-M 30, c d c 23-M 36$, $c d c 23-1 E 2$ or $c d c 23-D 587 A$ complemented switching defect of the $c d c 23-M 36$ mutant grown at $30^{\circ} \mathrm{C}$, the primase defective mutant $\mathrm{c} d c 23-D 588 A$ [29] and pol $\alpha$ genes did not (Fig. 3A). Surprisingly, a primase proficient mutant E586A also failed to complement the switching defect (Fig. 3A). Analysis of DNA prepared by conventional method paralleled the complementation data (Fig. 3B), showing that transformants containing wild-type $c d c 23^{+}, c d c 23-M 30, c d c 23-M 36, c d c 23-1 E 2$ or $c d c 23-D 587 A$ complemented the imprinting defect, but $c d c 23-D 586 A$, cdc23-D588A and pol $\alpha$ did not (Fig. 3B). Herein, the inability of primase proficient mutant E588A to complement the imprinting defect paralleled its inability to complement the switching defect. This surprising finding was also reported earlier [29] wherein the E588A mutant was found to ineffective in complementing the growth defect of the mcm104 mutant of $S$. cerevisiae. This discrepancy was ascribed to the effect of E588A mutant on function of the adjoining catalytic site of primase or on protein-protein interactions [29].

The results with DNA prepared in plugs with and without alkali treatment showed that plasmids bearing $c d c 23^{+}$and $c d c 23-M 36$ restored the alkali-labile bond at mat1 in cdc23-M36 mutants when cultured at $30^{\circ} \mathrm{C}$ (Fig. 3C, compare lanes 7 and 8 with lanes 3 and 4 ), while plasmids bearing the primase defective $c d c 23-D 588 A$ gene did not (Fig. 3C, lane 9).

As the primase function of Mcm10 has not been demonstrated in other orthologs [31], we tested for the primase activity of the purified recombinant GST-tagged Cdc23. Results showed that GST-Cdc23 does possess primase activity when assayed by measurement of the amount of pyrophosphate released due to the primase activity(Fig. 
3D)._Taken together, these results confirmed the primase function of Cdc 23 from $S$.

pombe and identified a novel function of $\mathrm{Cdc} 23$ primase in imprinting, a result

consistent with the possibility of ribonucleotide(s) constituting the imprint moiety.

\section{Genetic and biochemical Interactions of Cdc23 with Swi1, Swi3 and Swi7}

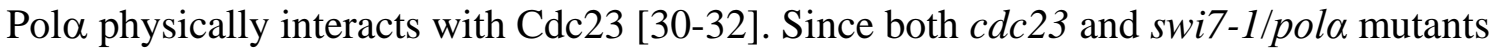
are defective in imprinting, we tested genetic interaction between their mutations. The double mutant showed much reduced sporulation efficiency, indicating reduced rate of switching on minimal medium at $30^{\circ} \mathrm{C}$ (Fig. EV5A). This result indicated that both these factors are required at different steps in imprinting. Surprisingly, unlike the single mutants, the double mutant failed to grow on rich media at $30^{\circ} \mathrm{C}$ (Fig. EV5C).

We also investigated genetic interactions of $c d c 23$ mutant with swil and swi3 mutants in switching and viability. Interestingly, $c d c 23-M 36$ mutant showed cumulative effect on switching efficiency in combination with swil and swi3 mutants on minimal medium at $30^{\circ} \mathrm{C}$ (Fig. EV5B), suggesting that $\mathrm{Cdc} 23$ and Swi1/Swi3 may act at different steps of imprinting. The double mutants of $c d c 23$ with swil and swi3 mutants also showed synthetic lethality on rich medium at $30^{\circ} \mathrm{C}$ (Fig. EV5D). The discrepancy between growth on minimal medium and lack of growth on rich medium at $30 \mathrm{oC}$ is surprising. It may reflect that the double mutants affect some important physiological function during vegetative growth but not during starvation.

We further investigated direct biochemical interactions in vivo and in vitro. Pol $\alpha^{+} \mathrm{p}$ could be readily co-immunoprecipitated with $\mathrm{Cdc} 23^{+}-\mathrm{HA}$ but in comparison the mutant Pol ${ }^{7-}$ ${ }^{1} \mathrm{p}$ was less efficiently co-immunoprecipitated (Fig. 4A). In vitro pull-down experiments showed that MBP-Pola $\alpha^{+}$interacted more strongly with GST-Cdc23 than with GST$\mathrm{Cdc}_{23}{ }^{\mathrm{M} 36}$ (Fig. 4B, panels I and II; Fig. 4C). Likewise, Pol $\alpha^{7-1}$ interacted more strongly with $\mathrm{Cdc} 23^{+}$than with $\mathrm{Cdc} 23^{\mathrm{M} 36}$ (Fig. 4B, panels III and IV; Fig. 4C). Furthermore, 
Cdc23 interacted with Pol $\alpha^{+}$more strongly than with Pol ${ }^{7-1}$ (Fig. 5B, compare panels I and III, panels II and IV; Fig. 5C). The order of strength of interaction was Pol $\alpha^{+}-$ $\mathrm{Cdc}_{23}{ }^{+}>\mathrm{Pol \alpha}^{\mathrm{Swi7-1}}-\mathrm{Cdc} 23^{+}>\mathrm{Pol \alpha}^{+}-\mathrm{Cdc} 23-\mathrm{M} 36=\mathrm{Pol \alpha}^{\text {Swi7-1 }}-\mathrm{Cdc} 23-\mathrm{M} 36$. As Cdc23 recruits Pol $\alpha$ to chromatin [33-35], our results suggest that the recruitment of Pol $\alpha$ may be reduced in swi7-1 and $c d c 23-M 36$ mutants.

A trivial possibility to explain our genetic results could be reduction in the level of Pol $\alpha$ in $c d c 23$ mutants, as inactivation of $\mathrm{Cdc} 23$ homolog, $\mathrm{Mcm} 10$, is known to cause rapid loss of Pola in S. cerevisiae [33]. However, western blot analysis shows that, compared to the wild type strain, the level of Pol $\alpha$ is not reduced significantly in $c d c 23-M 36$ mutant grown at $25^{\circ} \mathrm{C}$ and $30^{\circ} \mathrm{C}$ (Fig. 4D).

Interestingly, co-immunoprecipitation experiments also showed that $\mathrm{Cdc} 23$ interacts with Swi1 but not Swi3 in vivo (Fig. 4E, 4F). Thus, Cdc23 may also act at a common step involving Swi1 and Pol $\alpha$.

Our study was initiated to address the mechanism of action of catalytic subunit of DNA Pol $\alpha$ in strand-specific imprinting at the matl locus in $S$. pombe, which imparts competence to switch cell type in the following cell division [1,2]. Swi1 and Swi3 function to produce replication pause at the imprint site $[7,9]$ and at a centromereproximal replication termination sequence [36]. While Swil and Swi3 play an important but indirect role by providing a paused replication fork to promote imprinting, the enzymatic activity catalyzing the imprint was not known. Given its role in lagging strand synthesis $[11,37]$, we investigated whether the catalytic subunit of Pol $\alpha$ plays a direct role in imprinting.

As the imprint is either a nick [12] or 1/2 ribonucleotide insertion [7], our initial investigation addressed the possibility of Pol $\alpha$ causing a nick. We discounted this 
possibility because mutations in two potential endonuclease sequence motifs complemented the imprinting defect of the swi7-1 mutant. Most surprisingly, even a catalytically dead pold ${ }^{D 984 N}$ mutant gene was complementation proficient. Although the Pol ${ }^{\mathrm{D} 984 \mathrm{~N}}$ mutant protein forms a stable complex with the primase Spp1 and Spp2 subunits, the catalytic subunit fails to extend the RNA primer synthesized by the primase subunit $[21,22]$. The puzzling effect of the catalytically dead Pol $\alpha$ in restoring the imprint motivated us to investigate whether a step of DNA replication, earlier than the Okazaki fragment synthesis, is critical for imprinting. None of the components of the MCM helicase complex was found to involved in imprinting. Likewise, the Sppl and Spp2 primase subunit mutants showed normal imprinting. Finally, mutants of the noncanonical primase $c d c 23 / \mathrm{Spmcm} 10$ gene were found to be defective in imprinting.

Mcm10/Cdc23 has been studied both in S. cerevisiae and S. pombe. In vitro studies have shown that the SpCdc23 makes 2-20nt long RNA primers, which are then transferred to and extended by the catalytic subunit of Pola [29]. Notably, it is the Nterminal domain of $\mathrm{Cdc} 23$ that recruits Pol $\alpha$ to replication fork $[29,30]$. Taken together with the in vitro and in vivo studies showing a reduced ability of mutant Cdc23-M36 to interact with Pola, as well as, that of Cdc23 with Pol $\alpha^{7-1}$, these results suggest that both interaction of Cdc23 with Pol $\alpha$ along with its own primase-like function are required for imprinting (Fig. 5). It is pertinent that even a short, 2-ribonucleotide primer synthesized by Cdc23 can be extended into a DNA chain by Pol $\alpha$ [29]. As the imprint is constituted by a diribonucleotide insertion [14], we suggest that primers as short as 2 ribonucleotides, that are synthesized by primase domain of Cdc 23 at the mat1 locus, can be extended into a DNA chain by the catalytic domain of Pol $\alpha$; Pol $\alpha$, in turn, is recruited through N-terminal domain of Cdc23 [29,30]. It is puzzling how such an event could occur at the pause site. In this regard it has been shown that multiple rounds of primer synthesis occur at replication pause site [38]. Furthermore, these two ribonucleotides 
may not be processed by $\mathrm{RNaseH}$ and could be ligated with the properly processed end of the adjacent Okazaki fragment, thus catalyzing the imprint. Alternatively, incomplete processing of the RNA primers at the imprint site by RNaseH (which may be a result of replication pausing) may leave behind unprocessed 1-2 ribonucleotides to be ligated with the adjacent Okazaki fragments.

Interestingly, the residue D588 is conserved between S. pombe and metazonas, including human, mice, Xenopus [29], though the mammalian homologs have been shown to lack primase activity in vitro [31,39]. However, given the presence of an extra domain in the metazoan orthologs [39], a developmental control of primase activity through the extra domain may occur. Further studies are required to decipher such a possibility.

Furthermore, the reduced binding of Cdc23-M36 to Pol $\alpha^{+}$and still poorer binding to Pol $\alpha^{7-1}$, may impede extension of RNA primers by the Pol $\alpha^{7-1}$. This idea can explain the cumulative reduction we observed in imprinting/switching of $c d c 23-M 36$, pol $\alpha^{7-1}$ double mutant on synthetic medium at $30^{\circ} \mathrm{C}$. (The synthetic lethality observed on rich medium at $30^{\circ} \mathrm{C}$ may be due to requirement for some essential vegetative processes). The ability of Pol ${ }^{\mathrm{D} 984 \mathrm{~N}}$ to restore imprinting in swi7-1 mutant may be ascribed to possible restoration of recruitment of Pola $\alpha^{\text {swi7-1 }}$ to a Cdc23-bound template to help extend the RNA primers. The interaction of Cd23 with Swil also suggests that the unique primase activity may occur through interaction of Cdc23 with Pol $\alpha$ and Swi1 at the pause site.

How imprinting is caused uniquely at matl locus remains a puzzle. One possibility is that nucleotide sequence and unique DNA/nucleoprotein architecture at the mat1 locus lead to a Swi1- and Swi3-dependent pause at the imprint site. This pause may facilitate localization of $\mathrm{Cdc} 23$ and Pol $\alpha$ to persist at the imprint site long enough to 
synthesize a 2-ribonucleotide primer, which is then extended by the catalytic subunit of Pol $\alpha$ during the elongation stage of DNA replication (Fig. 5). In addition, a weakened interaction of mutant Cdc23 with Pol $\alpha$ protein might also cause reduced sequence specificity to install the imprint. Indeed, multiple break sites have been reported on both strands distal to the imprint site at the matl locus in the swi7-1 mutant [40]. It was proposed that Pol $\alpha^{\mathrm{swi7-1}}$ may not be able to guide the endonuclease to the correct site [40]. In light of the present results, we suggest that the mutant Pol $\alpha^{\text {swi7-1 }}$ may cause multiple ribonucleotide insertions near the imprint site, creating fragile sites, which lead to DNA cleavage during DNA preparation. Recently, lysine-specific demethylases Lsd1 and Lsd2 proteins have also been shown to control replication pause at mat 1 to facilitate efficient imprinting [41]. In sum our results suggest that Cdc23 plays a more direct role in imprinting than the previously described factors.

Strand-specific incorporation of ribonucleotides as a part of asymmetric DNA replication contributing to generation of developmental asymmetry of sister cells appears to be a unique process [4]. This apparent uniqueness may be because searching it requires knowing the locus that is differentially modified on one of the sister chromatids leading to a specific asymmetric cell division during development in metazoans. We recently reported that such a mechanism of asymmetric cell division indeed operates in evolutionarily distant yeast, Schizosaccharomyces japonicus [42].

Widespread incorporation of ribonucleotides has indeed been reported during mitochondrial DNA replication [43]. Recently, a low level of ribonucleotide incorporation by both Pol $\alpha$ and Pol $\delta$ has been demonstrated [44], raising the possibility of ribnucleotide insertion in DNA during differentiation or to facilitate recombination [45]. Similarly, fragile sites existing in mammalian genome occur predominantly in ATrich sequences with a potential to form stem-loop structures, and are generated by the 
inhibitors of DNA synthesis that compromise replication by Pol $\alpha$ [46]. Interestingly, Mcm10 plays an important role in mammalian development- its mutation causes defective embryonic cell proliferation and lethality in mice [47]. Interestingly, the primary defect occurs during morula to blastocyst stage when the inner cell mass (ICM) is formed, which ultimately produces different organs of the body. Thus, Mcm10 may play a role in cell differentiation during mammalian development. Thus, it would be interesting to investigate the role of primases in generation of DNA fragile sites, the incorporation of ribonucleotide insertions at these sites and their possible role in asymmetric cell differentiation during development in metazoans. 


\section{Materials and \\ Methods}

Strains and plasmids. The list of strains, plasmids and oligos used in this study are provided in Tables EV1, EV2 and EV3, respectively (Expanded View). Media and growth conditions employed were as described [49]. The per cent switching efficiency was determined by using the equation: $100 \mathrm{X}$ [2(number of zygotes)/[2(umber of zygotes) + number of vegetative cells]. The transformant strains containing plasmid borne pol $\alpha$ or $c d c 23$ genes, expressed under the control of $n m t l$ or $n m t 41$ promoters, were assayed for complementation on plates containing the repressor, thiamine. Under these conditions, leaky expression was observed from the $n m t 1$ promoter [50] (Ahmed and Singh, unpublished). For viability assays, the cultures of the required strains were normalized to the same $\mathrm{OD}_{600}$, serially diluted 10 -fold and $5 \mu \mathrm{l}$ of each dilution was spotted on the required plates. Plates were incubated at $25^{\circ} \mathrm{C}$ for 5 days or $30^{\circ} \mathrm{C}$ for 3-4 days and then photographed.

Southern hybridization. DNA was prepared by the normal method as described earlier [49]. DNA samples, isolated from yeast cells were digested HindIII endonuclease, were subjected to agarose gel electrophoresis, followed by Southern blotting and hybridization, as described earlier [11]. Alternatively, DNA was prepared from cells embedded in agarose plugs and subjected to restriction endonuclease digestion and alkali treatment as previously described [7]. The 10.6kb mat1M-containing HindIII fragment was used as a probe for Southern analysis. For experiments sown in Fig. EV2, donor deleted strain was used which only contains the mat 1 locus, while mat2 and mat 3 loci have been deleted [51]. Normally the level of DSB is expected to be $\sim 25$ of mat1 DNA signal when DNA is prepared by the conventional method. However, observe a higher level of $\sim 35 \%$, which may be ascribed to partial shearing of the mat1 DNA during preparation. Further, the level of DSB observed in alkali blots is around $10-12 \%$ of matl DNA. The 2-3 fold difference between the two methods of DNA preparation can be explained by the fact that the DSB fragments observed in blots of alkalitreated plugs detect only the imprinted strand due to single strand being cleaved while in case of DNA prepared by the normal method both strands are detected as the mat1 DNA is 
subjected to DSB.

Iodine vapours-staining procedure of colonies used for quantifying switching efficiency.

The homothallic cells, called $h^{90}$ cells, efficiently switch their mating type. Thereby, yeast colonies are composed of an equal proportion of $\mathrm{P}$ and $\mathrm{M}$ cells. Cells of opposite type mate under nitrogen starvation conditions, and the resulting "zygotic" diploid cell undergoes meiosis and sporulation to produce four haploid spores, called ascospores. The spores synthesize starch, but the vegetative growing cells do not. Because starch readily reacts with iodine vapours, when exposed to iodine vapours, efficiently switching colonies stain black in colour while those of reduced switching mutants stain lighter [49]. This procedure was used to test complementation of switching defective mutants.

Primase Assay. Primase activity of $\mathrm{Cdc} 23$ was assayed according to et al. [48]. An oligo with the sequence: 5'..ACTTCGTCGACTTATAAAGACTGAAATGTAGCCTGAC....3' was used for the assay. 
bioRxiv preprint doi: https://doi.org/10.1101/303180; this version posted April 17, 2018. The copyright holder for this preprint (which was not certified by peer review) is the author/funder, who has granted bioRxiv a license to display the preprint in perpetuity. It is made available under aCC-BY-NC-ND 4.0 International license.

Acknowledgements. BS and KKB were supported by Senior Research Fellowships from

Council of Scientific and Industrial Research, New Delhi, India. We are grateful to P. Nurse, J.

Hurwitz, T. Wang and S. Kearsey for gifts of strains and plasmids. We thank L. Kaur for editorial help. This work received intramural support from Council of Scientific and Industrial Research, New Delhi, India. AK's research is supported by the Intramural Research Program of The National Institutes of Health, Frederick National Laboratory for Cancer Research. 
bioRxiv preprint doi: https://doi.org/10.1101/303180; this version posted April 17, 2018. The copyright holder for this preprint (which was not certified by peer review) is the author/funder, who has granted bioRxiv a license to display the preprint in perpetuity. It is made available under aCC-BY-NC-ND 4.0 International license.

\section{Author Contributions}

JS and AJSK conceptualized the research problem. JS, BS, KKB, ACK, and UU carried out the experiments. JSN and SS carried out the data analysis, JS and AJSK wrote and edited the manuscript. 
bioRxiv preprint doi: https://doi.org/10.1101/303180; this version posted April 17, 2018. The copyright holder for this preprint (which was not certified by peer review) is the author/funder, who has granted bioRxiv a license to display the preprint in perpetuity. It is made available under aCC-BY-NC-ND 4.0 International license.

Conflict of Interest:

The authors declare that there is no conflict of interest. 
bioRxiv preprint doi: https://doi.org/10.1101/303180; this version posted April 17, 2018. The copyright holder for this preprint (which was not certified by peer review) is the author/funder, who has granted bioRxiv a license to display the preprint in perpetuity. It is made available under aCC-BY-NC-ND 4.0 International license.

\section{References:}

1. Klar AJ (1987) Differentiated parental DNA strands confer developmental asymmetry on daughter cells in fission yeast. Nature 326: 466-470

2. Klar AJ (1990) The developmental fate of fission yeast cells is determined by the pattern of Inheritance of parental and grand parental DNA strands. EMBO J 9: 1407-1415

3. Egel $R$ (2005) Fission yeast mating-type switching: programmed damage and repair. DNA Repair (Amst) 4: 525-536

4. Klar AJ (2007) Lessons learned from studies of fission yeast mating-type switching and silencing. Ann Rev Genet 41: 213-236

5. Egel R, Eie, E. (1987) Cell lineage asymmetry of Schizosaccharomyces pombe: unilateral transmission of a high-frequency mating-type switching in diploid pedigrees. Curr Genet 3: 5-12

6. Miyata H, Miyata M (1981) Mode of conjugation in homothallic cells of Schizosaccharomyces pombe J Gen Appl Micro 27: 365-371

7. Dalgaard JZ, Klar AJ (1999) Orientation of DNA replication establishes mating-type switching pattern in S. pombe. Nature 400: 181-184

8. Egel R, Beach DH, Klar AJ (1984) Genes required for initiation and resolution steps of mating-type switching in fission yeast. Proc Natl Acad Sci USA 81: 3481-3485

9. Dalgaard JZ, Klar AJ (2000) swi1 and swi3 perform imprinting, pausing, and termination of DNA replication in S. pombe Cell 102: 745-751

10. Lee BS, Grewal SI, Klar AJ (2004) Biochemical interactions between proteins and mat1 cis-acting sequences required for imprinting in fission yeast. Mol Cell Biol 24: 98139822

11. Singh J, Klar AJ (1993) DNA polymerase-alpha is essential for mating-type switching in fission yeast. Nature 361: 271-273

12. Arcangioli, B. A site-and strand-specific DNA break confers asymmetric switching potential in fission yeast. EMBO J 17: 4503-4510

13. Vengrova S, Dalgaard JZ (2004) RNase-sensitive DNA modification(s) initiates S. pombe mating-type switching Genes Dev 18: 794-804

14. Vengrova S, Dalgaard JZ (2006) The wild type Schizosaccharomyces pombe mat1 imprint of two ribonulcoetides. EMBO Reports 7: 59-65

15. Holmes AM, Kaykov A, Arcangioli B (2005) Molecular and cellular dissection of matingtype switching steps in Schizosaccharomyces pombe. Mol Cell Biol 25: 303-311

16. Matsumura $\mathrm{H}$ et al. (2006) Crystal structure of intein homing endonuclease II encoded in DNA polymerase gene from hyperthermophilic archaeon Thermococcus kodakaraensis strain KOD1. Proteins 63: 711-715

17. Stoddard BL (2005) Homing endonuclease structure and function. Q Rev Biophys 38: 49-95

18. Bakhrat A, Jurica MS, Stoddard BL, Raveh D (2004)Homology Modeling and Mutational Analysis of HO Endonuclease of Yeast. Genetics 166: 721-728

19. Knizewski L, Kinch LN, Grishin NV, Rychlewski L, Ginalski K (2007) Realm of PD$(D / E) X K$ nuclease superfamily revisited: detection of novel families with modified 
bioRxiv preprint doi: https://doi.org/10.1101/303180; this version posted April 17, 2018. The copyright holder for this preprint (which was not certified by peer review) is the author/funder, who has granted bioRxiv a license to display the preprint in perpetuity. It is made available under aCC-BY-NC-ND 4.0 International license.

transitive metaprofile searches. BMC Str. Biol. 7: 40

20. Bhaumik D, Wang TS (1998) Mutational effect of fission yeast Pol alpha on cell cycle events. Mol Biol Cell 9: 2107-2123

21. Copeland WC, Wang TS (1993) Mutational analysis of the human DNA polymerase alpha. The most conserved region in alpha-like DNA polymerases is involved in metalspecific catalysis. J Biol Chem 268: 11028-11040

22. Tan S, Wang T (2000) Analysis of fission yeast primase defines the checkpoint responses to aberrant S phase initiation. Mol Cell Biol 20: 7853-7866

23. Griffiths DJF, Liu VF, Nurse P, Wang TSF (2001) Role of fission yeast primase catalytic subunit in the replication checkpoint . Mol Biol Cell 12: 115-128

24. Tan S, Wang TS (2000) Analysis of fission yeast primase defines the checkpoint responses to aberrant S phase initiation Mol Cell Biol 20: 7853-7866

25. Forsburg SL, Nurse $P$ (1994) The fission yeast cdc19+ gene encodes a member of the MCM family of replication proteins. J Cell Sci 107: 2779-2788

26. Coxon A, Maundrell K, Kearsey K (1992) Fission yeast cdc21+ belongs to a family of proteins involved in an early step of chromosome replication. Nucleic Acids Res 20: 5571-5577

27. Miyake S, Okishio N, Samejima I, Hiraoka Y, Toda T, Saitoh I, Yanagida M (1993) Fission yeast genes nda1+ and nda4+, mutations of which lead to $S$ phase block, chromatin alteration an Ca2+ suppression, are members of the CDC46/MCM2 family. Mol Biol Cell 4: 1003-1015

28. Takahashi K, Yamada Y, Yanagida M (1994) Fission Yeast minichromosome loss mutants mis cause lethal aneuploidy Mol Biol Cell 10: 1145-1158

29. Fien K, Hurwitz J (2006) Fission Yeast Mcm10 Contains Primase Activity. J Biol Chem 281: 22248-22260

30. Fien K, Cho V-S, Lee J-K, Raychaudhary S, Tappin I, Hurwitz J (2004) Primer utilization by DNA Polymerase $\alpha$-Primase Is influenced by Its Interaction with Mcm10p. J. Biol. Chem. 229: 16144-16153

31. Robertson PD, Warren EM, Zhang H, Friedman DB, Lary JW, Cole JL, Tutter AV, Nalter JC, Fanning E, Eichman EF (2007) Domain architecture and Biochemical characterization of vertebrate Mcm10. J Biol Chem 283: 3338-3348

32. Warren EM, Huang H, Fanning E, Chazin WJ, Eichman BF (2009) Physical Interactions between Mcm10, DNA, and DNA Polymerase $\alpha$. J Biol Chem 284: 24662-24672

33. Ricke RM, Bielinski AK (2004) Mcm10 regulates the stability and chromatin association of DNA Pol $\alpha$. Mol Cell 16: 173-185

34. Yang X, Gregan J, Lindner K, Young H, Kearsey SE. (2005) Nuclear distribution and chromatin association of DNA polymerase $\alpha$-primase is affected by TEV protease cleavage of Cdc23 (Mcm10) in fission yeast. BMC Mol Biol 6: 13.

35. Zhu W, Ukomadu C, Jha S, Senga T, Dhar SK, Wohlschlegel LK, Kornbluth A, Dutta A. (2007) Mcm10 and And-1/CTF4 recruit DNA polymerase a to chromatin for initiation of DNA replication. Genes Dev 21: 2288-2299 
bioRxiv preprint doi: https://doi org/10.1101/303180; this version posted April 17, 2018. The copyright holder for this preprint (which was not certified by peer review) is the author/funder, who has granted bioRxiv a license to display the preprint in perpetuity. It is made available under aCC-BY-NC-ND 4.0 International license.

36. Dalgaard JZ, Klar AJ (2001) A DNA replication-arrest site RTS1 regulates imprinting by determining the direction of replication of mat1 in S. pombe. Genes Dev 15: 2060-2068

37. Masai H, Matsumoto S, You Y, Yoshizawa-Sugata N, Oda M (2010) Eukaryotic Chromosomal DNA replication: Where, when and how? Ann Rev Biochem 79: 89-130

38. Van C, Yan S, Micheal WM, Waga S, Cimprinch KA (2010) Continued primer synthesis at stalled replication forms contributes to checkpoint activation. J. Cell Biol 189: 233-246

39. Thu YM, Bielinski AK (2007) Enigmatic roles of Mcm10 in DNA Replication. Trends Biochem Sci 38: 184-194

40. Nielsen O, Egel R (1989) Mapping the double-strand breaks at the mating-type locus in fission yeast by genome sequencing. EMBO J 8: 269-276

41. Holmes A, Roseaulin L, Schurra C, Waxin H, Lambert S, Zaratiegui M, Martienssen RA, Arcangioli B (2012) Lsd1 and Isd2 control programmed replication fork pauses and imprinting in fission yeast. Cell Reports 2: 1513-1520

42. Yu C, Bonaduce MJ, Klar AJS (2013) Defining the epigenetic mechanism of asymmetric cell division of Schizosaccharomces japonicus yeast. Genetics 193: 85-94

43. Yang MY, Bowmaker M, Reyes A, Vergani L, Angeli P, Gringeri E, Jacobs HT, Holt IJ (2002) Biased incorporation of ribonucleotides on the mitochondrial L-strand accounts for apparent strand-asymmetric DNA replication Cell 111: 495-505

44. Nick McElhinny SA, Watts BE, Kumar D, Watt DL, Lundström EB, Burgers PM, Johansson E, Chabes A, Kunkel TA (2010) Abundant ribonucleotide incorporation into DNA by yeast replicative polymerases. Proc Natl Acad Sci USA 107: 4949-4954

45. Dalgaard JZ (2012) Causes and consequences of ribonucleotide incorporation into nuclear DNA. Trends Genet 28: 592-597

46. Durkin SG, Glover TW (2007) Chromosome fragile sites. Ann Rev Genet 41: 169-192

47. Lim HJ, Jeon Y, Jeon $\mathrm{CH}$, Kim JH, Le H (2011) Targeted disruption of Mcm10 causes defective embryonic cell proliferation and embryonic lethality. Biochim Biophys Acta 1813: $1777-1783$

48. Biswas T, Resto-Roldan E, Sawyer SK Artsimovich I, Tsodikov OV (2013) A novel nonradioactive primase pyrophosphatase activity assay and its application to the discovery of inhibitors of Mycobacterium tuberculosis primase DnaG. Nucleic Acids Res 41: e56

49. Moreno S, Klar AJ, Nurse $P$ (1991) Molecular genetic analysis of fission yeast Schizosaccharomyces pombe. Methods Enz 194: 795-823

50. Forsburg SL (1993) Comparison of Schizosaccharomyces pombe expression systems. Nucleic Acids Res 21: 2955-2956

51. Klar AJ, Miglio LM (1986) Initiation of meiotic recombination by double-strand DNA breaks in S. pombe. Cell 46: 725-731 


\section{Figure Legends}

Figure 1. Schematic diagram depicting the organization of mating-type loci in S. pombe. A, The loci mat1, mat 2 and mat 3 are located in $\sim 30 \mathrm{~kb}$ region of chromosome 2 . They comprise short conserved homology regions $\mathrm{H} 1$ to $\mathrm{H} 3$, which flank the $\sim 1.1 \mathrm{~kb}$ allele-specific sequences. Following imprinting occurring at the boundary of matl and the allele-specific region (dark blue triangle), a copy of the donor locus (mat2 or mat3) is transposed to the mat1 locus resulting in its switching by gene replacement. Replication fork progression from the centromere distal direction is met by a pause site (MPS1, blue triangle; 9), while fork from the left side encounters the replication termination sequence (RTS; 36). B, A schematic showing the HindIII restriction pattern of the mating type region with the corresponding picture observed following Southern blot hybridization using the mat $1 P$ or $M$ fragment of 10.6 as a probe (C), wherein mat1, mat 2 and mat 3 loci migrate at the positions of 10.6, 6.2 and $4.3 \mathrm{~kb}$, respectively. Occurrence of imprint at mat 1 generates a fragile site, which appears as a double strand break (DSB) generating the bands of 5.6 and $5.0 \mathrm{~kb}$ when DNA is prepared by the conventional method (left lane). Due to lack of imprint no DSB is seen in swil, swi3 or swi7 mutants. D, Schematic representation of the methodology used to detect a nick as the imprint, which can be visualized by 2-dimensional gel electrophoresis. (Top panel) DNA is prepared in plugs and then resolved by acrylamide gel electrophoresis in the first dimension, while the $2^{\text {nd }}$ dimension is run in a denaturing gel. Alternatively, samples embedded in agarose are digested with HindIII and then subjected to electrophoresis in native agarose gel without or with alkalitreatment (lower panel).

Figure 2. Role of Cdc23/SpMcm10 in Imprinting at the mat1 locus. A, Structure of $\mathrm{Cdc} 23$ protein, indicating the $\mathrm{N}$-terminal domain required for binding with ssDNA and DNA Pol $\alpha$, the Zinc finger domain and the C-terminal domain performing the RNA polymerase function. Locations of mutations M30, M36 and 1E2 in the N-terminal domain and D588A in the C-terminal RNA polymerase domain are shown (adapted from Ref. 29). B, Iodine-staining phenotypes of the indicated strains in $h^{90}$ background after growth on $\mathrm{PMA}^{+}$ plates at $25^{\circ} \mathrm{C}$ or $30^{\circ} \mathrm{C}$. C, Schematic showing the process of preparation of DNA by normal method or in plugs.* represents bands due to mating type rearrangements. $\mathbf{D}, c d c 23$ mutants exhibit imprinting defect. DNA was prepared and analyzed by the standard method. E, DNA was prepared in plugs from indicated cultures grown at $25^{\circ} \mathrm{C}$ or $30^{\circ} \mathrm{C}$, without (left panel) and with alkali treatment (right panel) followed by Southern blotting.

Figure 3. Primase domain of Cdc23 is essential for imprinting. A, Iodine-staining 
phenotypes of $h^{90}, c d c 23-M 36$ mutant transformed with plasmids bearing indicated $c d c 23$ gene mutations and grown on selective medium plates at $30^{\circ} \mathrm{C}$. B-C, $c d c 23$ genes having mutation in primase domain fail to complement the imprinting defect of the $c d c 23-M 36$ mutant. DNA was prepared from transformants of $c d c 23-M 36$ mutant with the indicated high copy plasmids containing the indicated genes and grown at 30oC. B, DNA was prepared by the conventional method. C, DNA was prepared in agarose plugs. Lane labeled wt indicates DNA prepared from wild type strain. Vector only lane shows cross-reacting vectors backbone bands (marked by *) present in all lanes, while bands marked (\#) correspond to mating-type rearrangements. DNA was digested with HindIII and subjected to agarose gel electrophoresis. C, DNA prepared in plugs was gel was blotted run without (left panel) and with alkali treatment (right panel) from strains grown at $30^{\circ} \mathrm{C}$. After Southern blotting membranes were subjected to hybridization. D, Cdc23 possesses primase activity. The amount of PPi released by primase assay was assayed according to [49 ].

Figure 4. Reduced interaction of Cdc23 and Pol $\alpha$ mutant proteins. A, Co-IP of HA-tagged Cdc23 with Pol $\alpha$ and Pol $\alpha^{\text {swi7-1 }}$. Inputs blot shows equivalent amounts of HAtaged Cdc23, Pol $\alpha$ and Pol $\alpha^{\text {swi7-1 }}$ was present in the indicated strains. Western; IP was performed with anti-HA antibody followed by immunoblotting with anti-HA and anti-Pola antibodies. B,C, In vitro interactions. B, Identical amounts of MBP-Pol $\alpha$ (panels I and II) and MBP-Pol $\alpha^{\text {swi7-1 }}$ (panels III and IV) were bound to amylose beads and incubated with increasing concentrations of the normalized amounts of GST-Cdc23 (panels I and III) and GST-Cdc $23^{\mathrm{M} 36}$ (panels II and IV), as indicated. Following SDS-PAGE of the bound proteins, the blots were probed with anti-MBP (panels I and II) and anti-GST antibodies (panels III and IV). C, Quantitation of MBP-Pol $\alpha$ and MPB-Pol $\alpha^{\text {swi7-1 }}$ binding with $\mathrm{Cdc} 23$ and $\mathrm{Cdc} 23^{\mathrm{M} 36} . \mathrm{X}$ axis shows the concentration of $\mathrm{Cdc} 23$ or $\mathrm{Cdc} 23^{\mathrm{M} 36}$ and the $\mathrm{Y}$ axis shows the ratio of Pol $\alpha$ or Pol $\alpha^{\text {swi7-1 }}$ to input GST-Cdc23 or GST-Cdc23 ${ }^{\mathrm{M} 36}$. D, No deleterious effect of $c d c 23 M 36$ mutation on the level of DNA Pol $\alpha$. Equal amounts of proteins prepared from wt and $c d c 23-$ M36 mutant grown at $25^{\circ} \mathrm{C}$ and $30^{\circ} \mathrm{C}$ were subjected to SDS-PAGE and western blotting with anti-Pol $\alpha$ and anti- $\alpha$-tubulin antibodies. E-F, Coimmunoprecipitation experiment showing that Cdc23 interacts with Swi1 (E) but not with Swi3 (F) in vivo. Strains without tag or the indicated tags for Cdc23 (HA) and Swi1 (TAP) and Swi3 (myc) were used for immunoprecipitation followed by immunoblotting with the indicated antibodies.

\section{Figure 5. A model visualizing the role of Cdc23 Primase and DNA Pol $\alpha$ during} lagging strand synthesis in generating the imprint at mat1 locus. Pausing at the imprint site by Swi1 and Swi3 may lead to allow Cdc23 primase to interact with Swi1 and to linger at the pause site for prolonged period during elongation phase of DNA replication. This 
bioRxiv preprint doi: https://doi.org/10.1101/303180; this version posted April 17, 2018. The copyright holder for this preprint (which was not certified by peer review) is the author/funder, who has granted bioRxiv a license to display the preprint in perpetuity. It is made available under aCC-BY-NC-ND 4.0 International license.

may allow synthesis a short primer of 2 ribonucleotides length, which is subsequently extended by the catalytic subunit of Pol $\alpha$. 
A

Fig. 1

D mat3M $\mathrm{H} 3 \mathrm{H} 2 \mathrm{H} 1$

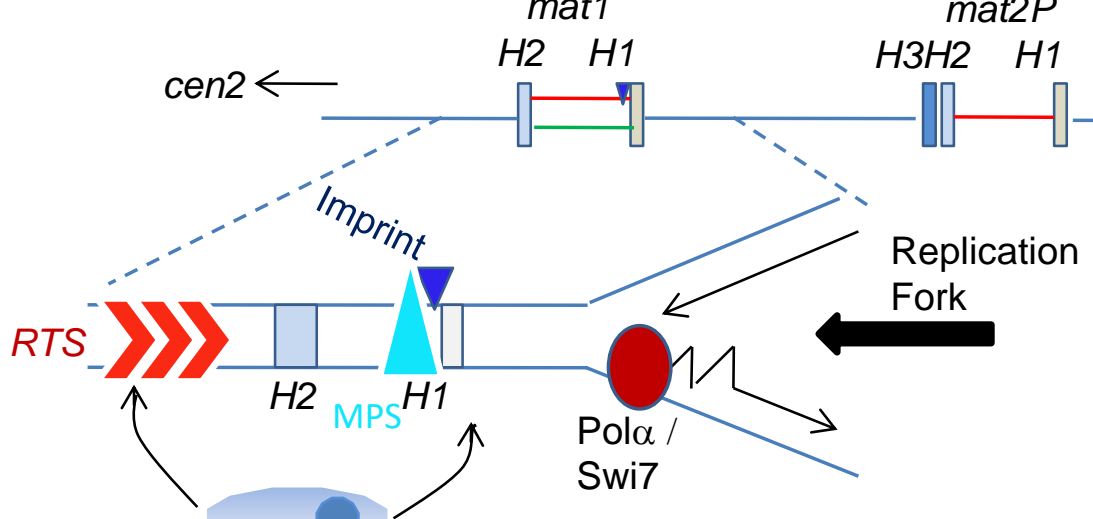

Swi1.Swi3

B

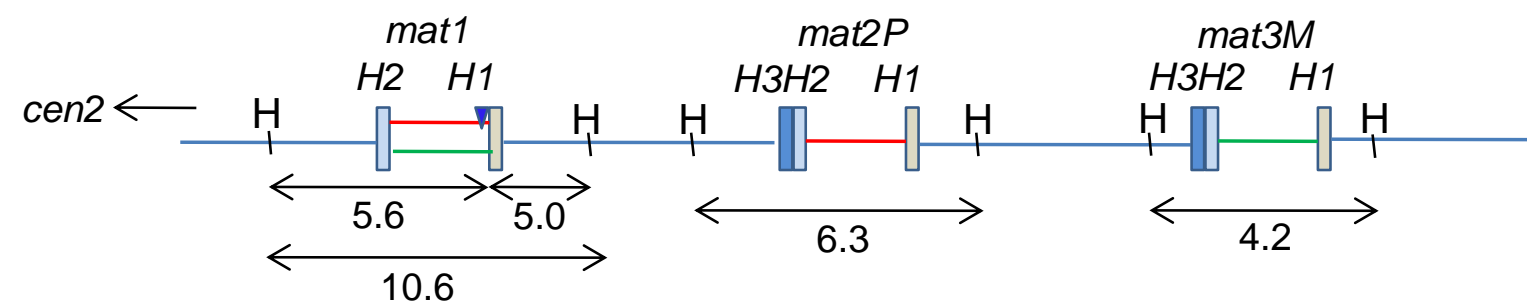

Probe

C

DNA Normal Method

\section{wt swi7}

mat1 $10.6 \mathrm{~kb}$

mat2 - $6.3 \mathrm{~kb}$

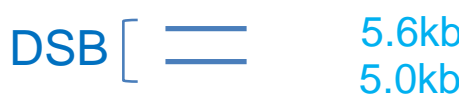

mat3 $-4.2 \mathrm{~kb}$
D DNA in agarose plugs

Single strand nick

Arcangioli, 1998

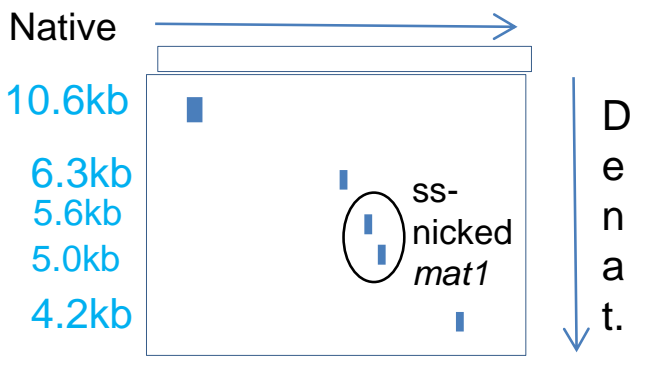

(theoretical illustration)

Or

Alkali-labile bond

(ribonucleotide insertion)

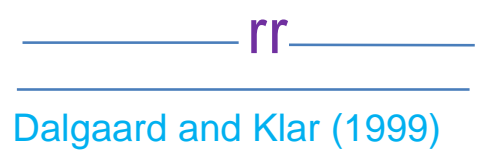

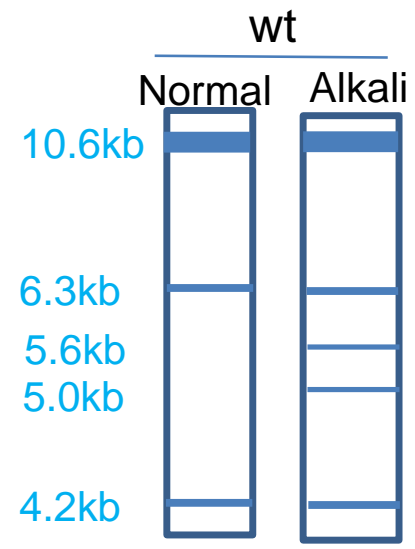




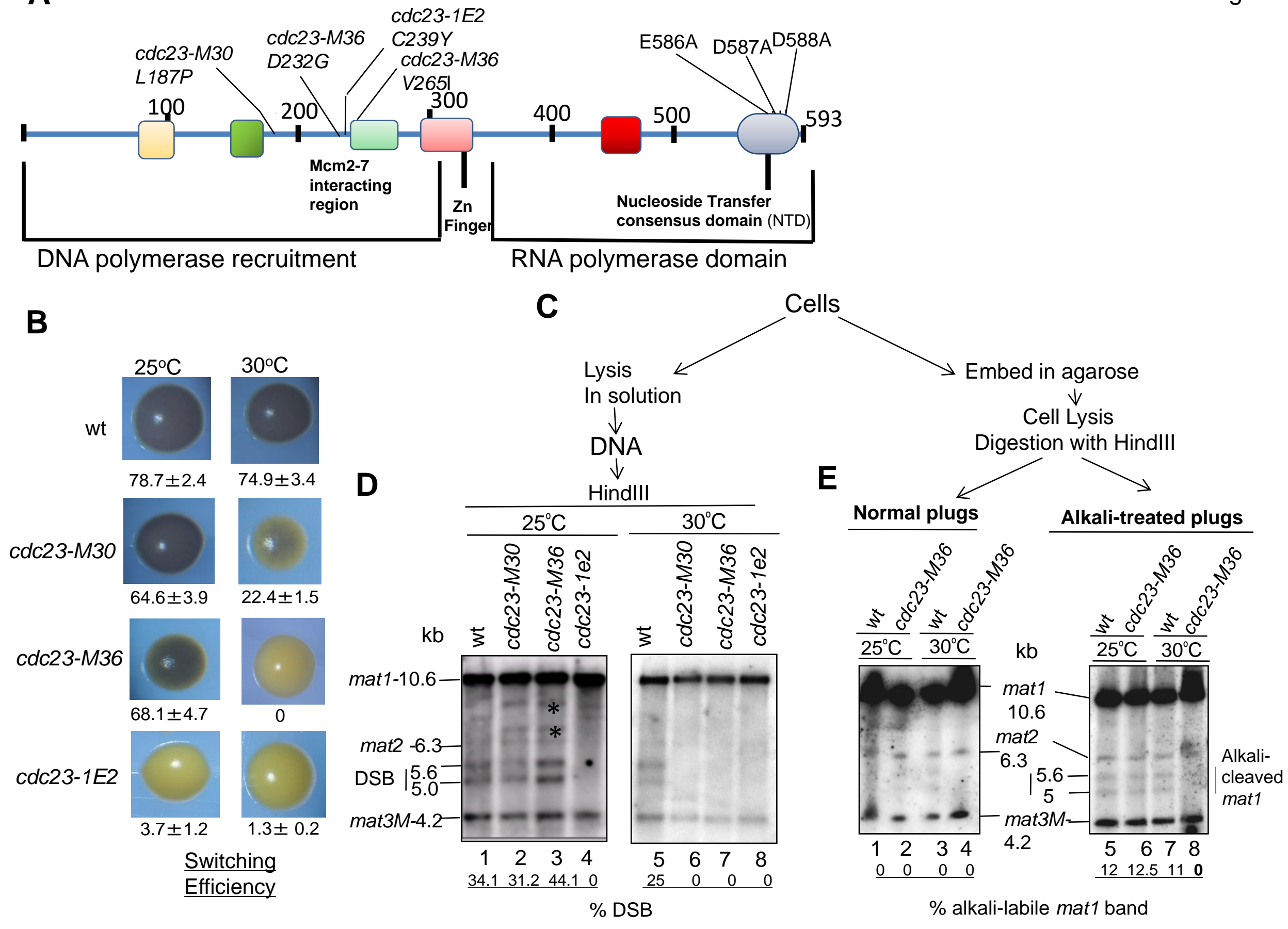




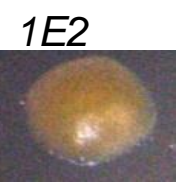
E586A



D588A



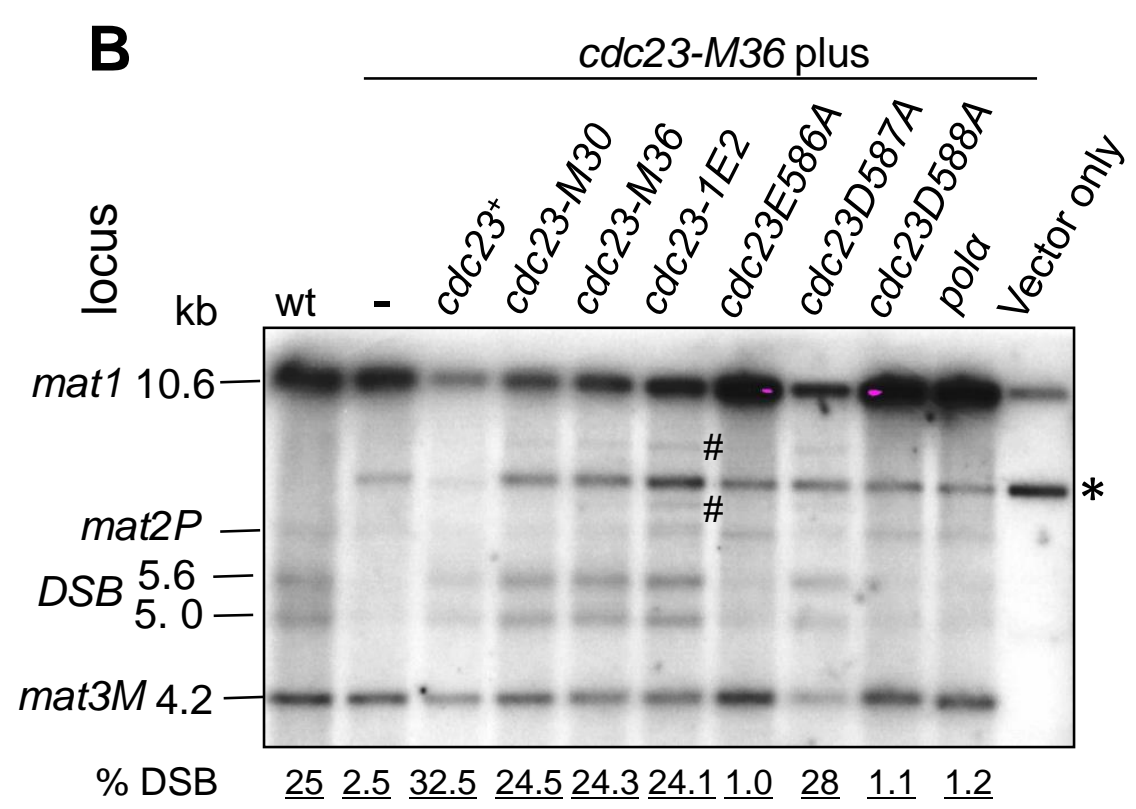

D

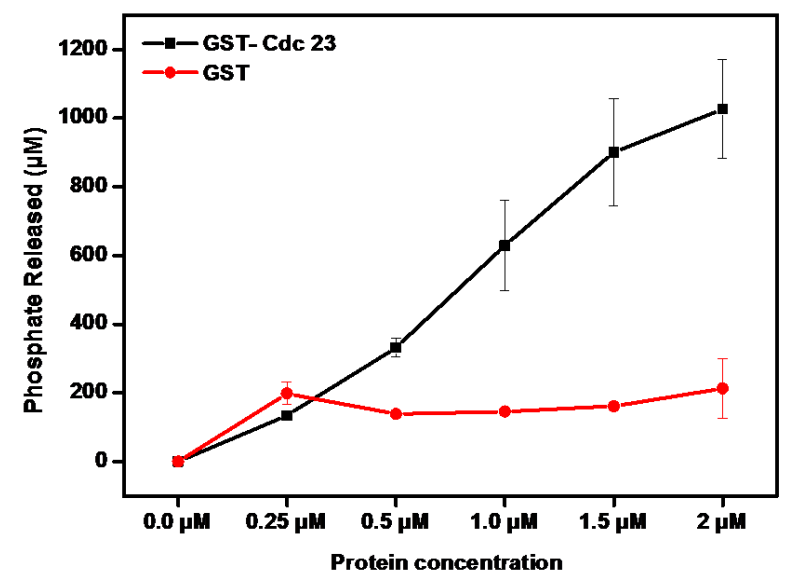

C Normal plugs

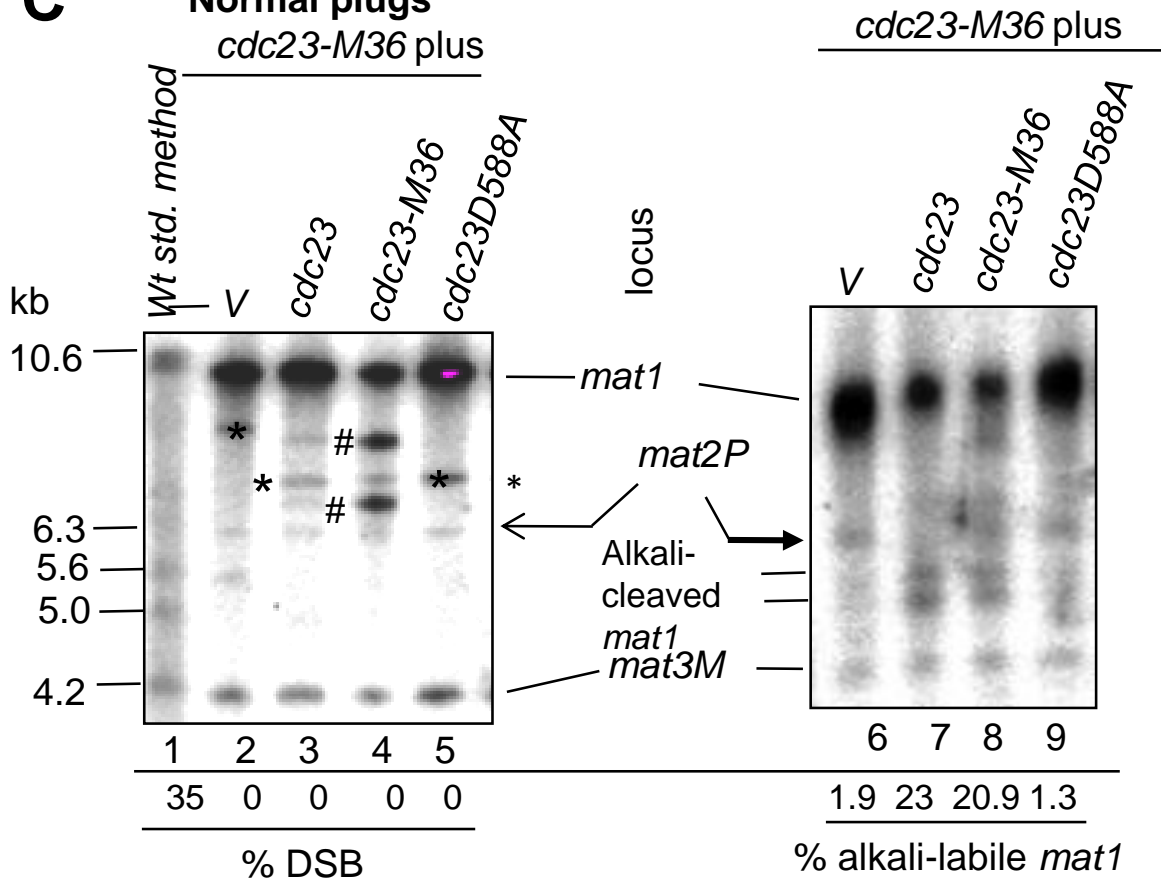

Alkali-treated plugs cdc23-M36 plus 
A

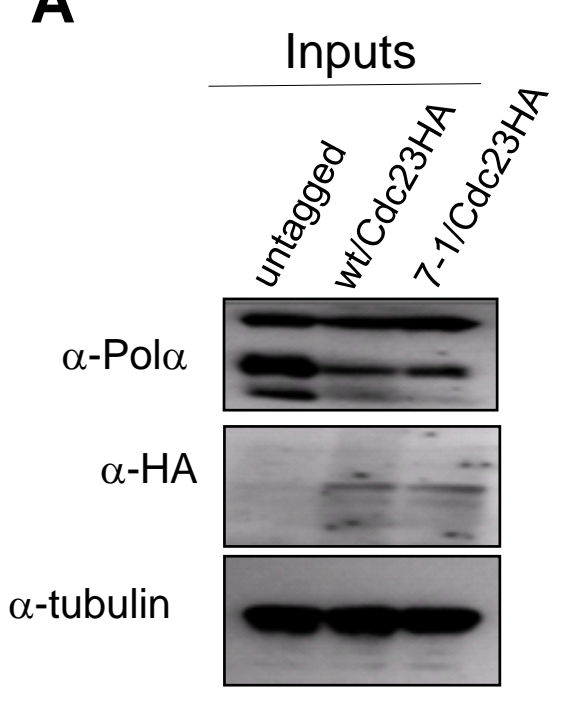

\section{Westerns} IP: $\alpha \mathrm{HA}$

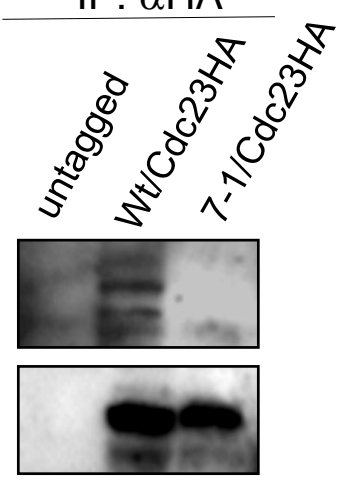

C

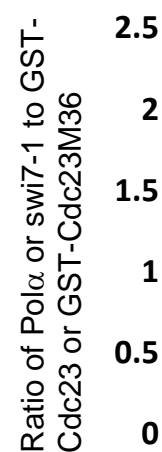

$\begin{array}{lllll}0.25 & 0.5 & 1.0 & 2 & 4\end{array}$

Concentration of GST Cdc23/M36 extract in mg

Fig. 4

B

Amylose resin

Vector control

MBP-Pol $\alpha^{+} /$MBP-Pol $\alpha^{\text {Swi7-1 }}$

GST-Cdc23+Cdc23 ${ }^{\mathrm{M} 36}$

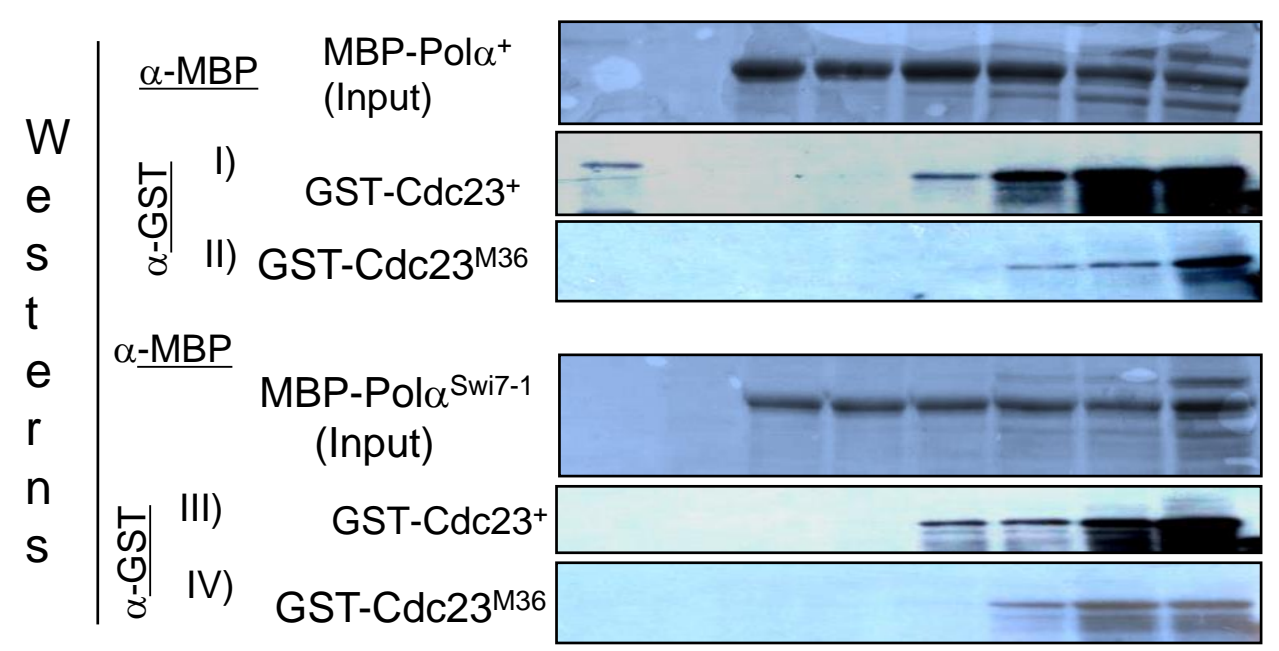

$$
\begin{array}{llllllll}
1 & 2 & 3 & 4 & 5 & 6 & 7 & 8 \\
+ & + & + & + & + & + & + & +
\end{array}
$$$$
\begin{array}{cccccccc}
- & + & - & - & - & - & - & - \\
- & - & + & + & + & + & + & +
\end{array}
$$$$
5 x \quad 1 x-1 x \quad 2 x-3 x-4 x-5 x
$$

E

E

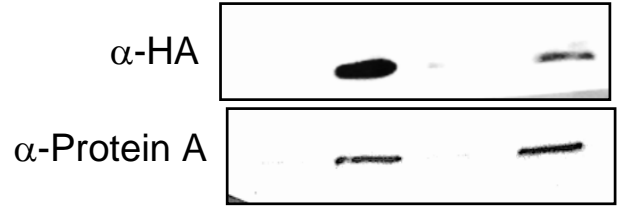

$\mathbf{F}$

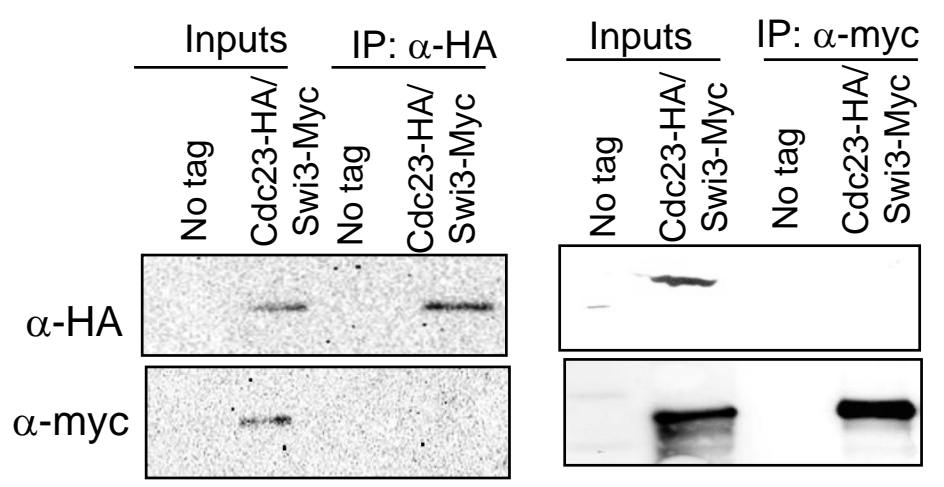


Fig. 5
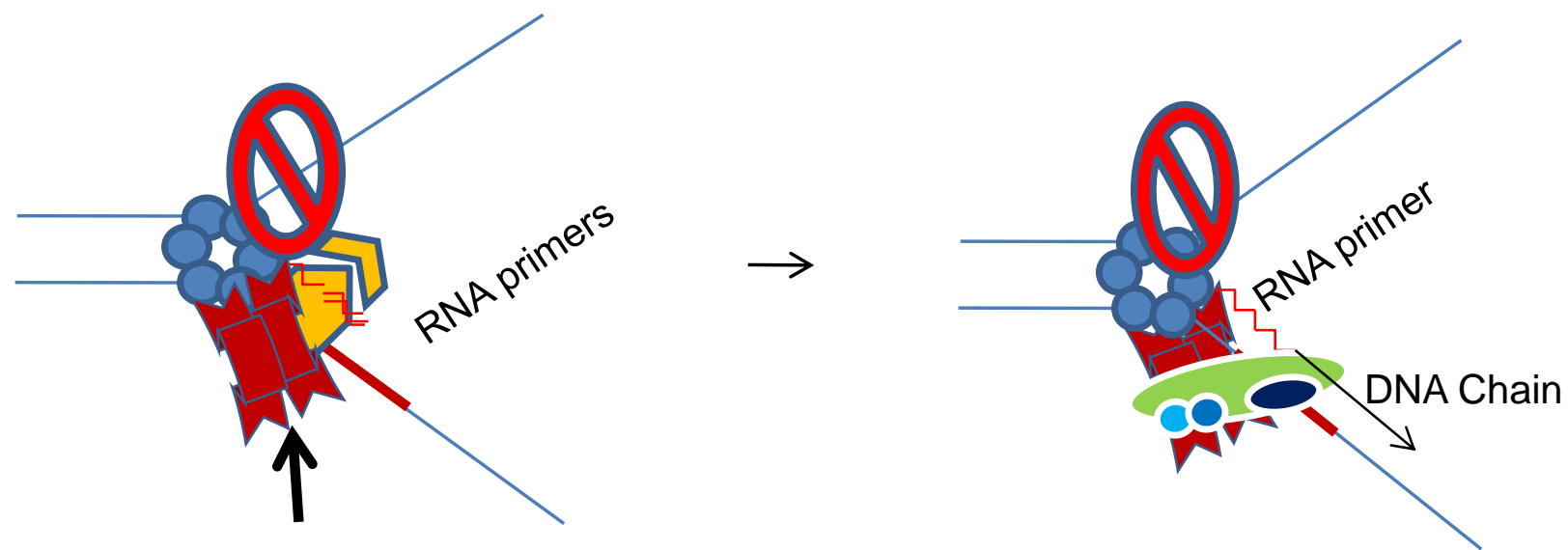

Paused Replication Fork
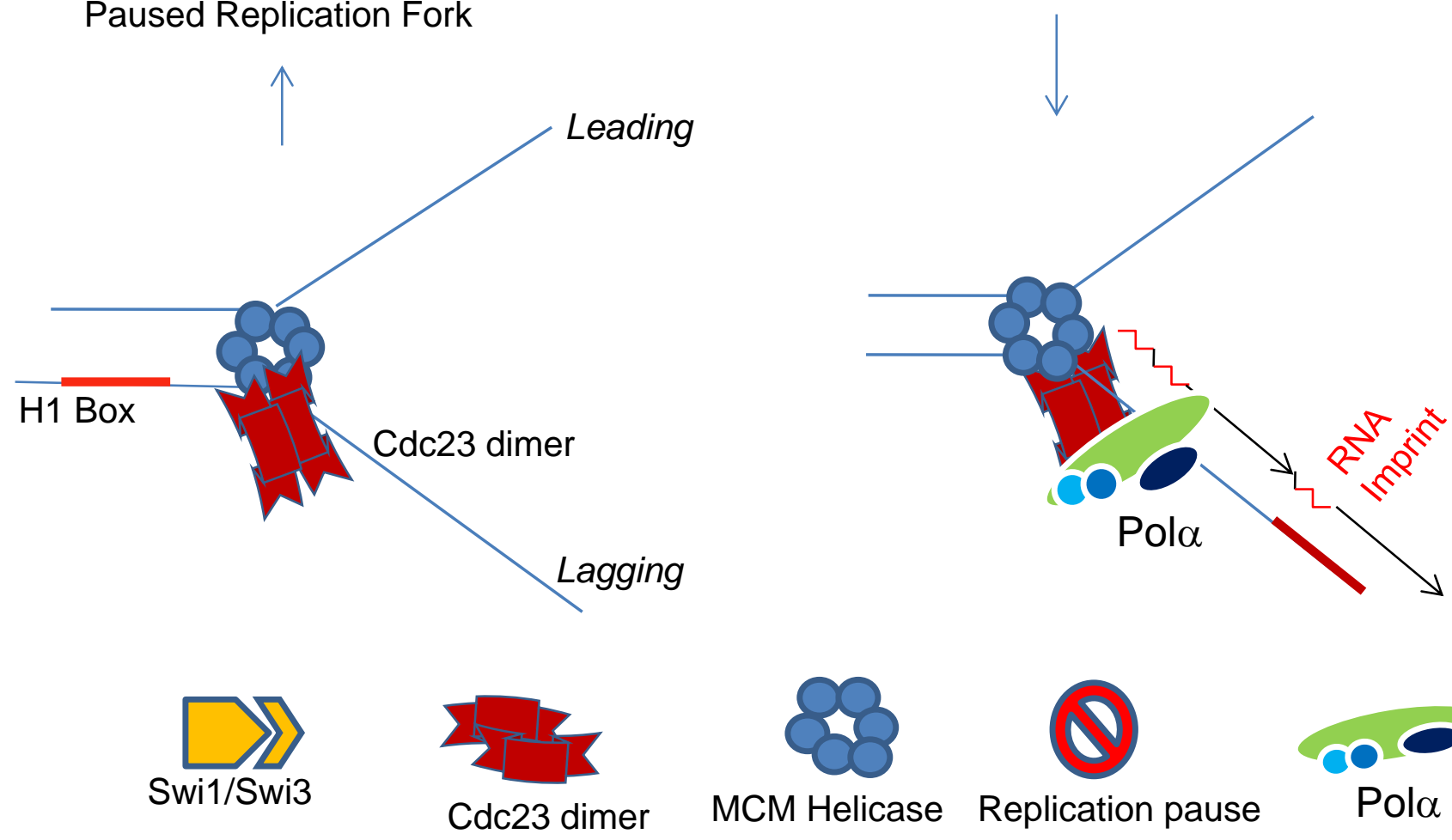

MCM Helicase Replication pause



